\title{
Statistics and Analysis of the Relations between Rainstorm Floods and Earthquakes
}

\author{
Baodeng Hou, ${ }^{1}$ Yongxiang $\mathrm{Wu},{ }^{2}$ Jianhua Wang, ${ }^{1}$ Kai $\mathrm{Wu},{ }^{2}$ and Weihua Xiao \\ ${ }^{1}$ China Institute of Water Resources and Hydropower Research, State Key Laboratory of Simulation and \\ Regulation of Water Cycle in River Basin, Beijing 100038, China \\ ${ }^{2}$ Nanjing Hydraulic Research Institute, State Key Laboratory of Hydrology-Water Resources and Hydraulic Engineering, \\ Nanjing 210029, China
}

Correspondence should be addressed to Jianhua Wang; jhwangiwhr@126.com

Received 13 November 2015; Revised 21 February 2016; Accepted 4 April 2016

Academic Editor: Paolo Madonia

Copyright $\odot 2016$ Baodeng Hou et al. This is an open access article distributed under the Creative Commons Attribution License, which permits unrestricted use, distribution, and reproduction in any medium, provided the original work is properly cited.

The frequent occurrence of geophysical disasters under climate change has drawn Chinese scholars to pay their attention to disaster relations. If the occurrence sequence of disasters could be identified, long-term disaster forecast could be realized. Based on the Earth Degassing Effect (EDE) which is valid, this paper took the magnitude, epicenter, and occurrence time of the earthquake, as well as the epicenter and occurrence time of the rainstorm floods as basic factors to establish an integrated model to study the correlation between rainstorm floods and earthquakes. 2461 severe earthquakes occurred in China or within $3000 \mathrm{~km}$ from China and the 169 heavy rainstorm floods occurred in China over the past 200+ years as the input data of the model. The computational results showed that although most of the rainstorm floods have nothing to do with the severe earthquakes from a statistical perspective, some floods might relate to earthquakes. This is especially true when the earthquakes happen in the vapor transmission zone where rainstorms lead to abundant water vapors. In this regard, earthquakes are more likely to cause big rainstorm floods. However, many cases of rainstorm floods could be found after severe earthquakes with a large extent of uncertainty.

\section{Introduction}

The Global Climate Change led to the frequent hazards like flood and draught; meanwhile, it also exerted a certain impact on geological hazards like earthquake $[1,2]$. The related research concluded that the earthquake had a certain impact on the climate change [3]. China is one of the countries with the most types of natural calamities in the world. Occurrence of natural calamities will lead to certain losses of human lives and damage to our living environment. In particular, concentrated or successive occurrence of such severe disasters within a short period of time may result in even greater harms to personal safety and social and economic fortunes [4].

Frequent occurrence of rainstorm flood, drought, earthquake, and other natural disasters has driven the rapid development of some emerging sciences, for example, geosystemics [5] and disaster physics [6]. The researches on the disaster chain (DC) [7] are also gradually deepening; for example, geophysical disaster chain (GDC) has been rapidly developed in recent years [8]. GDC as a new transdisciplinary science primarily studies such disaster chains as earthquake and flood, drought and earthquake, earthquake and typhoon, earthquake and desertification/sand storm, and earthquake and cold wave as well as air pollution and lightning, wherein the chains of earthquake and flood, flood and earthquake, and drought and earthquake as well as earthquake and drought have major impacts on people's daily life and urban development and therefore have become a focus of relevant experts and scholars.

But few people study GDC out of China. GDC was first put forward by three academics in China named Z. J. Guo, A. N. Guo, and K. X. Zhou. Y. Q. Wang, Q. Hou, L. T. Du, J. G. Gao, and Q. G. Geng also studied it. They defined DC as a phenomenon of different kinds of significant disasters occurring in the neighborhood or remote areas within a certain period and believe that GDC is a member of DC, which can lead to large disaster, so the most attention was 
paid to it. At present, the studies mainly focused on the definition of DC, formation mechanism and characteristics, damage assessment, risk assessment, and integrated disaster reduction countermeasures [9-11].

Whether DC or GDC, the key lies in the "Chain," namely, whether the relationships among these disasters existed, whether these disasters will be able to form a "Chain," and whether to produce "Chain Reaction" [12] or "Catastrophe" [13-16], thus leading to greater disasters. As the "Butterfly Effect" [17] implies, there may be significant relationships among some seemingly unrelated things. There are many complicated trigger factors of these geophysical disasters, such as earthquakes, rainstorm floods, droughts, and typhoons. Each factor appears to be independent, but some small relationship may exist among them, and then they influence each other to form a "Chain Reaction." Now that the "Chain Reaction" does exist, it will always be repeated and present some regularity. This paper was studied based on this fact to explore the regularity between the successively occurred rainstorm floods and earthquakes.

It is well known that earthquake can be induced by external factors. Fluid injection in the subsurface can generate earthquake. Some examples are the KTB site-1994 in Germany [18], Soultz-2000 in France [19], or Basel-2006 in Switzerland [20]. It is noteworthy that injection of fluids, such as magma or water, can initiate seismic swarms: for example, reservoir (or large artificial lake) induced earthquake [21], water table changes or stream discharge connected with microearthquake [22], intraplate earthquake swarms [23], fluid injections [24-26], magma injection [27], and aftershocks of strong earthquakes [28, 29]. As suggested by Shapiro et al. [30], microseismic series associated with fluid injection (including magma) could be linked to big earthquakes.

But there are limited researches on the correspondence between rainstorm floods and earthquakes abroad; the researches are mainly concentrated on the relations between earthquakes and tsunamis [31-33] and earthquakes and fire $[34,35]$. In 1965, the international tsunami prewarning system was formally launched. In 1966, 26 countries and regions cooperated to set up Pacific Tsunami Warning Center [36] in Hawaii at the request of the IOC (Intergovernmental Oceanographic Commission) [37]. Thereafter, a couple of regional and national tsunami warning centers were established successively, for example, Hawaii Tsunami Warning Center, Alaska and Western Coast Tsunami Warning Center, and Japan Tsunami Warning Center. In the 1990s, the UN established an international coordination group for the Pacific Tsunami Prewarning System. In 1997, someone proposed including the Indian Ocean into the tsunami prewarning system but failed. In October 2003, Australian seismologist Dr. Phil Cummins proposed expanding the scope of prewarning to the Indian Ocean again during the International Tsunami Organization Conference but was also rejected. Through the computer-synthesized tsunami wave height diagrams of four stations including Cocos Islands, he simulated the tsunami induced by the Mw8.5 earthquake of Sumatra in 1833 in a highly similar way to the earthquakeinduced tsunami of 2004 .
Several Chinese researchers believed that there was a certain relation between rainstorm floods and earthquakes [3840]. They proposed that the occurrence of flood, drought, and other natural calamities after an earthquake might relate to the earth degassing effect which is both the cause and effect of an earthquake. This indicates that the foregoing viewpoints are basically in line with each other; that is, substantial humid and hot gases are released after an earthquake, thus causing severe rainstorm floods, namely, the earth degassing effect (EDE) [41].

Are earthquake and rainstorm flood related? Will a severe earthquake spark off a severe flood? Will the occurrence of a severe flood induce a severe earthquake? There have always been disputes about these questions in the academic field. Both earthquakes and floods relate to an enormous spatial and temporal system and have highly complicated physical causes, so the mechanism-related researches are very difficult. It is noteworthy that there is still no solution to earthquake forecast worldwide today. As such, it is highly difficult to research into the "Disaster Chain" that may exist between earthquakes and floods and the relevancy and physical causes thereof. Therefore, this study ignored the physical mechanism and only performed a preliminary study on the spatial and temporal correspondence between rainstorm floods and earthquakes from a statistical perspective. Meanwhile, a quantitative computing model was established to study the rules of spatial and temporal correspondence between rainstorm floods and earthquakes when EDE was considered.

\section{The Concept of EDE and Preliminary Analysis}

2.1. The Concept of EDE. The concept of EDE was first proposed by former Soviet scholars in the early 1900s. With subsequent development over centuries, the New Independent States of the former Soviet Union remain dominant power in terms of in-depth research [40]. The essence of this concept is that mantle ichor (HACONS supercritical fluid) [42] is spontaneously emitted in an upward and outward direction, resulting in the formation of five gas rings and gas geodynamics. Through alkali metasomatism, upwelling mantle ichor could lead to alteration and magma. Meanwhile, it could also cause original upper mantle and crust in the solid form to degenerate. As a result, under a combined effect of the three basic dynamics of the earth (i.e., gravity, earth's rotation, and differential rotation) and celestial tidal force (e.g., mainly from the moon), the tectonic movement of the earth, associated evolutionary process, and natural disasters could be induced.

2.1.1. Gases in the Earth Crust. In recent hundreds of years, under the constraints of solid earth concept, the EDE was ignored, although the combustible gases in underground were mined by humans and the huge plume of gases were spewed by strong volcanos. The evidences of gases in the earth's crust were as follows: (i) Germany KTB Well: there was a high conductivity layer in the depth of $7.0 \mathrm{~km}$, with hot brine flow of gas [43]; (ii) Russia Cora KTB Well: there 


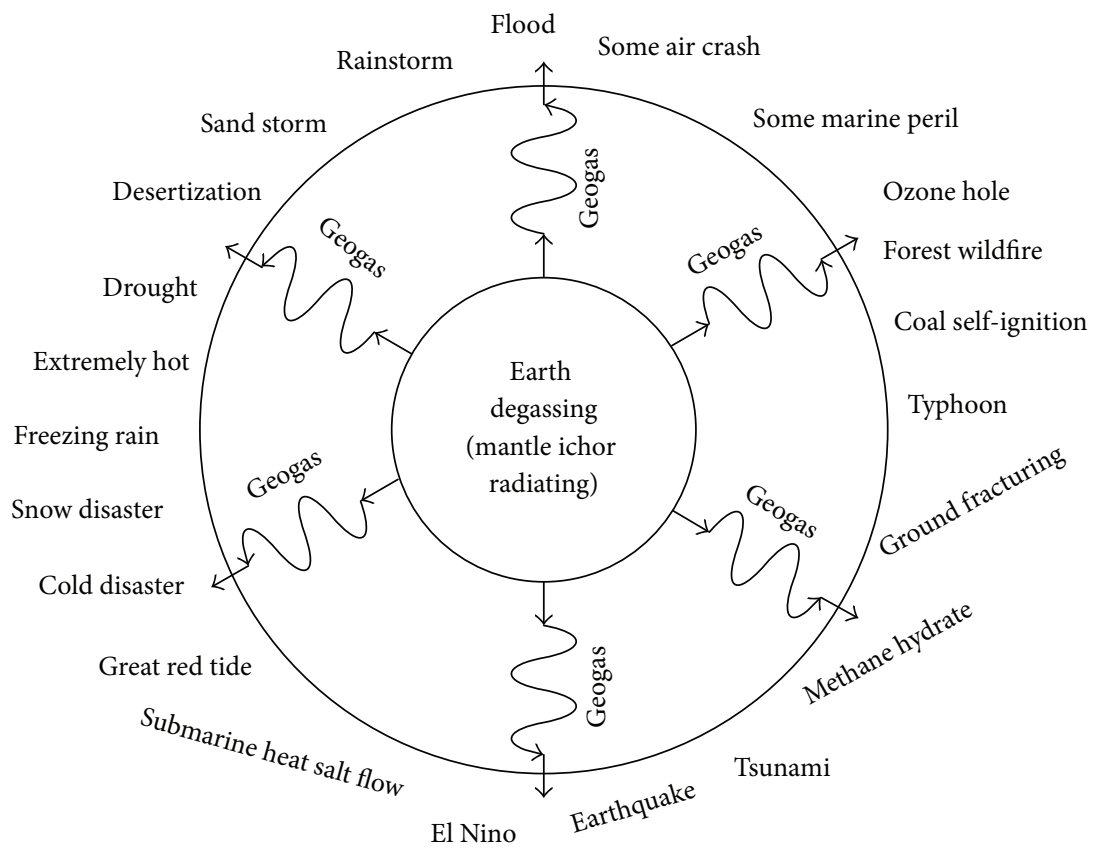

FIgURE 1: The relationship between earth degassing and some disasters.

was a high permeability zone and gas flow in the depth of $11.5 \mathrm{~km}$ [44]; (iii) Russia Kolva KTB Well: high porosity hole was found in the depth of $5.2 \mathrm{~km}$ [44]; (iv) Russia Tyumen region: there was rich water and gas in the depth of $7416 \mathrm{~m}$ [44]; (v) Kazakhstan Tengiz region: there was low density, low stress, porosity, and saturation fluid from the oil and gas layer to $15 \mathrm{~km}$ [45]; (vi) there was some finding recently in [46, 47]. The research of Vernadsky [48], Rubey [49], Goldschmidt [50], Fanale [51], Bailey [52], Gold [53], Pineau and Javoy [54], Graf et al. [55], Chiodini et al. [56], and other scholars has improved the recognition of the importance of EDE. EDE is likely to be the inoculated disaster condition and trigger factor of the disasters such as earthquake, drought, rainstorm, and flood (Figure 1) [40].

2.1.2. Degassing in the Earthquake. Driven by the huge earthquake, the gas in the interior of the earth will overflow up powerfully [41]. In the earthquake of Haicheng in 1975 and Longling, Tangshan, and Songpan in 1976, the black fog or odd fog appeared or black or white gas was jetted out, warm and wet. The temperature of the gas spewed before Songpan earthquake was $80 \sim 120^{\circ} \mathrm{C}$, and the plant leaves were scorched by the gas [57].

The gases in the upper mantle balloon are 120 times more than in the entire atmosphere, and the gases in the core are more than those in the upper mantle. Seismic activity caused the gathered gases in deep crust upward along the fault fracture zone and formed the gas accumulated in the local soil.

2.1.3. Degassing after Earthquake. Because of the complexity and obstruction of the underground fissure, the gases upward to the surface can be lagging more than one year after the earthquake.
Six months after the Sumatran earthquake in 2004, there were a large number of gases released in the quake zone. About 2 years later, the satellite thermal infrared image showed that the bright temperatures of the degassing sites were higher than surrounding region in the quake zone of the west of Kunlun Mountain Pass Ms8.1 earthquake in 2001. Research suggests that earthquake may play an important role in gas degassing from the solid earth [58].

As to the application of earth degassing-related theories to the flood-earthquake relevancy research, Du and other researchers believe that such relevancy exists because, during the process of earthquake preparation, accumulation, and outbreak, the produced earth degassing effect could lead to humid low-pressure environment in the lower layer of the atmosphere, which is conducive to the formation of heavy rain and subsequent flood events. In addition, a wide range of areas surrounding the border of Inner Mongolia, Xinjiang, and Gansu province in China where severe earthquakes hit exhibit relatively intense tectonic movement before, after, or when such events occur. The escaped hot water vapors from underground areas might also affect the dynamics of the westerly lands and cause big flood or drought events in the Yellow River Basin. After the occurrence of severe earthquake events in Yunnan province and Burma, a wide range of escaped water vapors are accumulated over the Bay of Bengal. Meanwhile, among water vapors transported towards Yangtze River Basin, the component of plum rain vapors is mostly from the Bay of Bengal, which brings about abundant supply of water vapors. As a result, big flood or drought events are likely to occur in this region. Moreover, the occurrence of large earthquake events in Sumatra Island, Indonesia, is closely related to the occurrence of large flood events in the Pearl River Basin. 
TABLE 1: The list of "earthquake-flood relevancy" events under the "earth degassing effect."

\begin{tabular}{|c|c|c|}
\hline Number & Earthquakes & Floods \\
\hline 1 & $\begin{array}{l}6 \text { destructive earthquakes in Shaanxi, Shanxi, and } \\
\text { Henan provinces from } 1568 \text { to } 1569\end{array}$ & $\begin{array}{l}\text { Severe flood at the borders of Shaanxi, Shanxi, and Henan } \\
\text { provinces in } 1570\end{array}$ \\
\hline 2 & $\begin{array}{l}\text { Earthquakes higher than Ms7 in the mountainous areas } \\
\text { in the upper reaches of the Yangtze River on April 11, } \\
1870\end{array}$ & Severe flood along the Yangtze River in 1870 \\
\hline 3 & $\begin{array}{l}\text { One earthquake higher than Ms7 and two earthquakes } \\
\text { higher than Ms6 at the border of Guangdong and } \\
\text { Fujian provinces from } 1918 \text { to } 1921\end{array}$ & $\begin{array}{l}\text { Landing of a super typhoon at the border of Guangdong and } \\
\text { Fujian provinces in } 1922\end{array}$ \\
\hline 4 & $\begin{array}{l}\text { An earthquake of Ms8.6 leading to 1,200 deaths in } \\
\text { Mongolia on December 4,1957 }\end{array}$ & $\begin{array}{l}\text { Severe flood along the Yellow River in July } 1958 \text { (peak } \\
\text { flowrate of } 22,300 \mathrm{~m}^{3} / \mathrm{s} \text { at Huayuankou on the } 16 \text { th) }\end{array}$ \\
\hline 5 & $\begin{array}{l}\text { Two earthquakes higher than Ms8 in Tibet in } 1950 \text { and } \\
\text { 1951; two earthquakes of Ms7.5 in Tibet and Gansu in } \\
1952 \text { and } 1954\end{array}$ & $\begin{array}{l}\text { Severe floods along the Yangtze River, the Huai River and the } \\
\text { Yellow River in 1954; severe flood on Songhua River in } 1956\end{array}$ \\
\hline 6 & $\begin{array}{l}\text { An earthquake of Ms7.5 in Ulan Bator of Mongolia on } \\
\text { January 5, } 1967\end{array}$ & $\begin{array}{l}\text { Severe flood along the Yellow River in August } 1967 \text { (peak } \\
\text { flowrate of } 21,000 \mathrm{~m}^{3} / \mathrm{s} \text { at Longmen on the 11th) }\end{array}$ \\
\hline 7 & $\begin{array}{l}\text { An earthquake of Ms7.1 in the southwest of Mongolia } \\
\text { on July } 4,1974\end{array}$ & $\begin{array}{l}\text { Severe flood in Zhumadian of Henan province on August 8, } \\
1975\end{array}$ \\
\hline 8 & $\begin{array}{l}\text { Earthquakes of Ms7.3 and } 7.4 \text { in Longling of Yunnan on } \\
\text { May 29, } 1976 \\
\text { Earthquake of Ms7.8 in Tangshan of Hebei province on } \\
\text { July 28, 1976, leading to 242,000 deaths } \\
\text { Earthquake of Ms7.2 in Songpan-Pingwu of Sichuan } \\
\text { province on August } 16 \text { and August 23, } 1976\end{array}$ & $\begin{array}{l}\text { Severe flood on the Yellow River in July and August } 1977 \\
\text { (peak flowrate of } 8,780 \mathrm{~m}^{3} / \mathrm{s} \text { at Dongguan Bridge, YanAn on } \\
\text { July 6, a millennial flood; peak flowrate of } 14,500 \mathrm{~m}^{3} / \mathrm{s} \text { at } \\
\text { Longmen on July 20; peak flowrate of } 10,800 \mathrm{~m}^{3} / \mathrm{s} \text { at } \\
\text { Huayuankou on August 7) }\end{array}$ \\
\hline 9 & $\begin{array}{l}\text { Earthquake of Ms7.5 in the north of Mandalay Burma } \\
\text { on January 5, } 1991\end{array}$ & Flood on Huai River in 1991 \\
\hline 10 & $\begin{array}{l}\text { Earthquake of Ms8.1 in the west of Kunlun Mountain, } \\
\text { Qinghai province on November 14, } 2001\end{array}$ & $\begin{array}{l}\text { Flood in the middle reaches of the Yellow River from August } \\
\text { to October } 2003\end{array}$ \\
\hline 11 & $\begin{array}{l}\text { Earthquake of Ms9.3 in Sumatra, Indonesia on } \\
\text { December 26, } 2004\end{array}$ & Flood on Xijiang River on June 17, 2005 \\
\hline 12 & $\begin{array}{l}\text { Four earthquakes of Ms6-6.5 in Yunnan and Burma } \\
\text { from May to June } 2007\end{array}$ & Super flood on Xijiang River in June 2008 \\
\hline
\end{tabular}

Table 1 for the "earthquake-flood relevancy" events may be subjected to the EDE in their view.

2.2. Preliminary Analysis. The foregoing analysis of the "earthquake-flood relevancy" events and "relevancy rules" shows the following.

\subsubsection{The "Earthquake-Flood Relevancy" Events Are Mostly} Single without Any Systematic and Comprehensive Researches Thereon. From the perspective of earthquake and flood scales, the earthquake scale was basically above 7 while the scales of floods were diverse, covering a range from several thousand square kilometers to several hundred thousand square kilometers. Any comparison of an earthquake higher than Ms7.0 with floods of different scales (e.g., comparison of a flood on the trunk of a large river and a flood on a certain small branch) might not be practically feasible.

From the perspective of occurring time, the two events occurred at an interval of at least half a year, and most over 1 year, or even 6 years at the maximum; for example, the earthquake on Ms8.5 at Chayu, Tibet, in August 1950 was associated with the floods on the Yangtze River in 1954 and the floods on Songhua River in 1956. Severe floods were focused in the period from June to August in China while severe earthquakes might occur every month.

From the regional perspective, typical severe floods were mostly concentrated in the middle and lower reaches of the seven major rivers in the east of China while major earthquakes were mostly concentrated in Xinjiang and Gansu in the northwest of China, Yunnan in the southwest, and Taiwan region. An initial comparison showed that the nearest pairs were more than $1,000 \mathrm{~km}$ away from each other. The distance was even farther if overseas earthquakes were considered; for example, the earthquake taking place in Sumatra of Indonesia was more than $4,000 \mathrm{~km}$ away from the severe flood along the Pearl River Delta. According to the earthquake-flood relevancy theory of Guo, this is the remote relevancy. According to such a viewpoint, however, most earthquakes and floods are related based on Table 1.

2.2.2. Superficial Understanding of the Physical Mechanism of "Earthquake-Flood Relevancy". According to the EDE, "earthquake-flood relevancy" mainly arises from the gases discharged during an earthquake. However, the foregoing analysis showed that earth degassing was both the cause and effect of an earthquake and the low-pressure environment 
TABLE 2: Summary of the eras of the representative rainstorm floods.

\begin{tabular}{lccccccccc}
\hline Era & Before 1900 & $1900-1949$ & $1950 \mathrm{~s}$ & $1960 \mathrm{~s}$ & $1970 \mathrm{~s}$ & $1980 \mathrm{~s}$ & $1990 \mathrm{~s}$ & After 2000 & Total \\
\hline Count & 15 & 75 & 17 & 18 & 10 & 11 & 24 & 9 \\
Percentage & $8.9 \%$ & $44.4 \%$ & $10.1 \%$ & $10.7 \%$ & $5.9 \%$ & $6.5 \%$ & $14.2 \%$ & $5.3 \%$ & $100.0 \%$ \\
\hline
\end{tabular}

TABLE 3: Summary of the occurrence periods of the representative rainstorm floods.

\begin{tabular}{lccccccc}
\hline Occurrence period & May & Jun. & Jul. & Aug. & Sept. & Oct. & Total \\
\hline Count & 4 & 41 & 64 & 51 & 7 & 2 & 169 \\
Percentage & $2.4 \%$ & $24.3 \%$ & $37.9 \%$ & $30.2 \%$ & $4.1 \%$ & $1.2 \%$ & $100.0 \%$ \\
\hline
\end{tabular}

TABLE 4: Summary of the region of the representative rainstorm floods.

\begin{tabular}{|c|c|c|c|c|c|c|c|c|c|c|c|}
\hline $\begin{array}{l}\text { Drainage } \\
\text { area or } \\
\text { region }\end{array}$ & $\begin{array}{l}\text { Songhua } \\
\text { River }\end{array}$ & $\begin{array}{l}\text { Liao } \\
\text { River }\end{array}$ & $\begin{array}{c}\text { Hai } \\
\text { River }\end{array}$ & $\begin{array}{l}\text { Yellow } \\
\text { River }\end{array}$ & $\begin{array}{l}\text { Huai } \\
\text { River }\end{array}$ & $\begin{array}{c}\text { Yangtze } \\
\text { River }\end{array}$ & $\begin{array}{l}\text { Pearl } \\
\text { River }\end{array}$ & Northwest & Southwest & $\begin{array}{l}\text { Zhejiang, } \\
\text { Fujian, and } \\
\text { Taiwan }\end{array}$ & Total \\
\hline Count & 14 & 17 & 17 & 9 & 17 & 47 & 28 & 4 & 4 & 12 & 169 \\
\hline Percentage & $8.3 \%$ & $10.1 \%$ & $10.1 \%$ & $5.3 \%$ & $10.1 \%$ & $27.8 \%$ & $16.6 \%$ & $2.4 \%$ & $2.4 \%$ & $7.1 \%$ & $100.0 \%$ \\
\hline
\end{tabular}

resulting from the earth degassing might attract humid and hot vapors and cold airs. Therefore, observation of substantial earth degassing effects may indicate the occurrence of a severe earthquake on the one hand and a severe flood or substantial local temperature decline on the other hand. Meanwhile, earth degassing is only a local effect which is not on the same level as the atmospheric circumfluence and the weather system that cause the flood. In terms of energy, the energy level of an earthquake is incomparable with the solar energy level that causes atmospheric circumfluence and weather system changes. Moreover, how can vapors discharged in an earthquake flow in the air for some years and then come back to the same drainage area in the same country? If the temperature increases due to an earthquake, what is the relation with an overseas earthquake? These questions cannot be well addressed.

Therefore, the relation between rainstorm floods and earthquakes as concluded by the foregoing researches is highly subjective, coincident, and uncertain.

\section{Data and Model}

3.1. Rainstorm Flood Data. After extensive examination of the rainstorm floods data in China, a total of 169 representative regional rainstorm floods characterized by long duration (over 3 days), wide coverage (covering area more than $100,000 \mathrm{~km}^{2}$ ), large scale, and rare occurrence (recurrence interval more than 20 years) from 1800 to 2012 were systematically summarized. For the convenience of analysis, each rainstorm flood was collectively taken as one event, and it was assumed that all the 169 rainstorm floods were rainstorm flood events with no further classification. As shown in Tables 2-4, the era, period, and region of the representative rainstorm floods were presented.

3.2. Seismic Data. Totally 2,461 cases of earthquakes were summarized (Figure 2), including 987 earthquakes on or higher than Ms6.0 in China mainland and neighboring

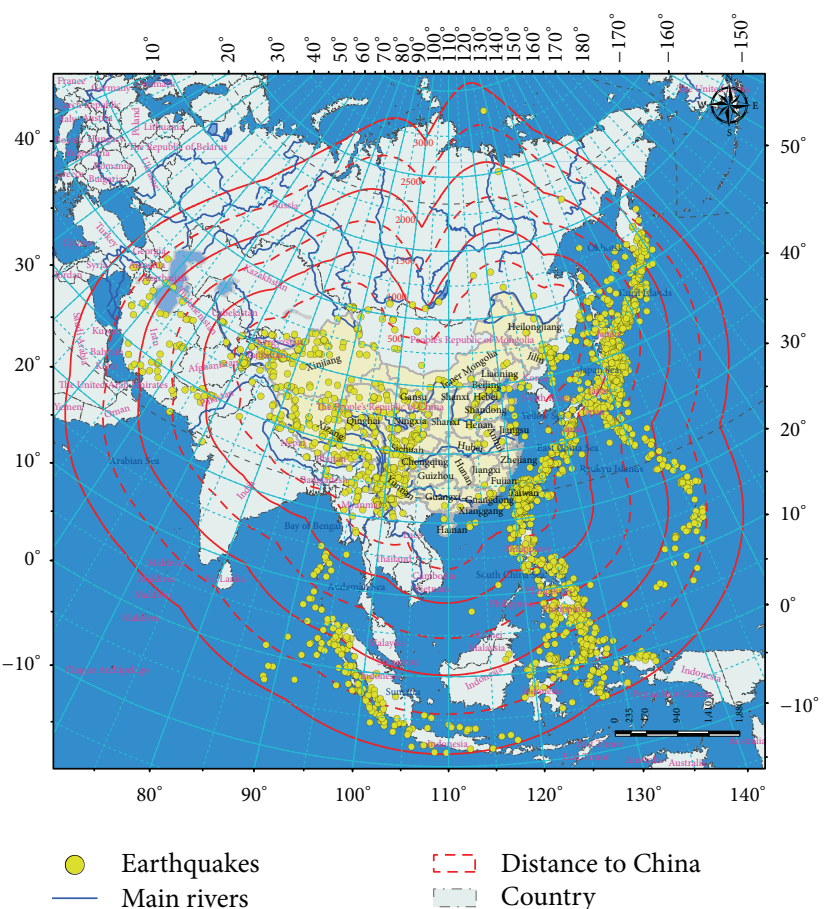

FIGURE 2: Distribution of the earthquakes higher than Ms6.0 in China and surrounding regions.

regions (Taiwan and territorial waters) from 1800 to 2012 and 1,474 earthquakes on or higher than Ms6.0 (higher than scale 6.5 for most earthquakes) within a distance of 3,000 km from China from 1900 to 2012. Among these earthquakes, there were 3 earthquakes on or higher than Mw9.0, 46 earthquakes on a scale of 8.0 to 9.0 (including 8.0 but excluding 9.0), 693 earthquakes on a scale of 7.0 to 8.0 , and 1,719 earthquakes on a scale of 6.0 to 7.0 .

As rainstorm flood events mostly occur in the east and south of China, the earthquakes taking place in neighboring 
countries are all far away from the place where the rainstorm flood events take place. Therefore, a preliminary screening was performed on the overseas earthquakes. According to the relevant data, the initial conclusion was that the overseas earthquakes lower than Ms6.5 had weak impacts on the rainstorm floods in China. As such, a total of 2,354 cases of severe earthquakes were screened out, including domestic earthquakes higher than Ms6.0 and overseas earthquakes higher than Ms6.5.

\subsection{Model}

3.3.1. Basic Philosophies of the Model. In order to further probe into the spatial and temporal correspondences between rainstorm flood events and earthquakes, it was assumed that the impacts of an earthquake on rainstorm flood will increase when the earthquake scale is higher, the time interval is shorter, and the distance is smaller. Considering earth degassing effects, the impact of an earthquake on a rainstorm flood will increase when the orientation of the epicenter to the rainstorm zone is less different from the orientation of vapor transmission above the rainstorm zone. According to this basic concept, only the postearthquake occurrence of rainstorm flood events was considered in the general calculation. Meanwhile, for the convenience of statistical analysis, the domestic territory and the regions within $3000 \mathrm{~km}$ from China firstly underwent a gridding process and were numbered according to some rules (see below). Secondly, the factors that affect the correspondence between the rainstorm floods and earthquakes were analyzed, identified, classified, and scored. Thirdly, various influential factors were weighted and the calculation model was established for general scoring and calculation of the relations between rainstorm floods and earthquakes. Finally, the possible correspondences between rainstorm floods and earthquakes were determined through classification of the general scores.

3.3.2. Gridding and Numbering. For the convenience of statistics, China and the regions within 3,000 km from China were first gridded with a size of $2.5^{\circ} \times 2.5^{\circ}$. The geographic range was $40^{\circ}$ east longitude and $10^{\circ}$ south latitude at the minimum and $170^{\circ}$ east longitude and $80^{\circ}$ north latitude at the maximum. For grid numbering, there was one grid at an interval of $2.5^{\circ}$ starting from $\left(40^{\circ},-10^{\circ}\right)$. The number was changed by 1 for each grid in the longitudinal direction and 100 for each grid in the latitudinal direction. The first grid was numbered as 101.

For any point $(x, y), x$ is the longitudinal coordinate, “+” is the east longitude, and "-_" is the west longitude; $y$ is the latitudinal coordinate, "+" is the north latitude, and " - " is the south latitude. The calculation formula of grid number AABB (AA may stand for one or two bits) is as follows:

$$
\mathrm{AABB}=\left\{\left[\frac{(y+10)}{2.5}\right]+1\right\} \times 100+\left[\frac{(x-40)}{2.5}\right]+1
$$

where [] is the rounding symbol.
For any grid number AABB, the central longitudinal and latitudinal coordinate $(x, y)$ of the grid is

$$
\begin{aligned}
& x=(\mathrm{BB}-1) \times 2.5+40+1.25 \\
& y=(\mathrm{AA}-1) \times 2.5-10+1.25
\end{aligned}
$$

3.3.3. Identification and Processing of Influential Factors. The above analysis showed that the following factors might affect the relations between earthquakes and rainstorm floods: earthquake scale, time interval and distance between the earthquake and the rainstorm flood, and the orientation of the earthquake relative to the rainstorm flood. In order to describe the spatial and temporal correspondence between earthquakes and rainstorm flood events as accurately as possible, it is necessary to classify the above factors and assign corresponding weights to them:

(1) Classify earthquake scales and weigh accordingly. It is believed that higher earthquake scale will cause greater impact on the rainstorm flood, so that the weight will be higher.

(2) Classify the time intervals between the earthquake and rainstorm flood (on a monthly basis) and weigh accordingly. It is believed that the impacts of an earthquake on the rainstorm flood will decline, and thus the weight will be smaller when the time interval between an earthquake and a rainstorm flood is longer.

(3) Classify the distance between the earthquake and rainstorm flood (in kilometers) and weigh accordingly. It is believed that the impacts of an earthquake on the rainstorm flood will decline, and the weight will be smaller when the distance between an earthquake and a rainstorm flood is farther.

(4) When EDE is substantiated, it is believed that the probability for an earthquake to impact the rainstorm flood will be higher and the weight should be higher if the earthquake and the vapors causing the rainstorm floods are in the same or similar orientation.

Eight orientations, that is, north, northeast, east, southeast, south, southwest, west, and northwest, were adopted herein to indicate the orientations of the earthquakes and the vapors causing the rainstorm floods, and eight codes from 1 to 8 were awarded thereto accordingly. The relative orientation of the earthquake to the rainstorm flood could be calculated based on the longitude and latitude of the epicenter and the rainstorm center. The orientation of vapors causing the rainstorm floods might be acquired according to relevant research results [59]. As rainstorms are mostly concentrated from June to August in most parts of China and heavy rainstorms in specific regions may occur in May or September to October, only the sources and relative orientations of vapors of various regions from May to October were summarized. Considering the gridding process, the sources and the relative orientations of the vapors causing the heavy rainstorms in the regions located in various grids in China from May to October will be summarized finally. If the orientation 
TABLE 5: Classification and weights of the influential factors for the relations between an earthquake and a rainstorm flood event.

\begin{tabular}{|c|c|c|c|c|c|c|c|}
\hline \multicolumn{2}{|c|}{ Magnitude } & \multicolumn{2}{|c|}{ Time interval (months) } & \multicolumn{2}{|c|}{ Distance $(\mathrm{km})$} & \multicolumn{2}{|c|}{ Orientation } \\
\hline Scale & Weight & Scale & Weight & Scale & Weight & $\begin{array}{c}\text { Orientation } \\
\text { difference }\end{array}$ & Weight \\
\hline $6.0 \sim 6.9$ & 0.1 & 0 & 1.0 & $0 \sim 499$ & 1.0 & $\begin{array}{c}\text { The same } \\
\text { orientation }\end{array}$ & 1.0 \\
\hline $7.0 \sim 7.4$ & 0.2 & $1 \sim 3$ & 0.8 & $500 \sim 999$ & 0.9 & $\begin{array}{c}\text { Different by } 1 \\
\text { orientation }\end{array}$ & 0.8 \\
\hline $7.5 \sim 7.9$ & 0.4 & $4 \sim 6$ & 0.7 & $1000 \sim 1499$ & 0.8 & $\begin{array}{l}\text { Different by } 2 \\
\text { orientations }\end{array}$ & 0.4 \\
\hline $8.0 \sim 8.4$ & 0.6 & $7 \sim 9$ & 0.6 & 1500 1999 & 0.7 & $\begin{array}{c}\text { Different by } \\
\text { over } 2 \\
\text { orientations }\end{array}$ & 0.1 \\
\hline $8.5 \sim 8.9$ & 0.8 & $10 \sim 12$ & 0.5 & $2000 \sim 2499$ & 0.6 & & \\
\hline $\begin{array}{l}\text { Higher than } \\
\text { scale } 9\end{array}$ & 1.0 & $13 \sim 15$ & 0.4 & 2500 2999 & 0.5 & & \\
\hline & & $16 \sim 18$ & 0.3 & $3000 \sim 3499$ & 0.4 & & \\
\hline & & 19 21 & 0.2 & $3500 \sim 3999$ & 0.3 & & \\
\hline & & $22 \sim 24$ & 0.1 & $4000 \sim 4499$ & 0.2 & & \\
\hline & & & & $\begin{array}{c}\text { Higher than } \\
4500\end{array}$ & 0.1 & & \\
\hline
\end{tabular}

of an earthquake to a rainstorm center is the same as the orientation of the transmission of the vapors within the grid where the rainstorm center is located, the code difference will be 0 ; if they are different by 1 orientation, the code difference will be 1 or 7 ; if they are different by 2 orientations, the code difference will be 2 or 6 ; if they are different by 3 orientations, the code difference will be 3 or 5; if they are different by 4 orientations, the code difference will be 4 .

Table 5 showed the classification and weights of various influential factors.

3.3.4. Weighing and General Calculation of the Influential Factors. After classification and weighing of various influential factors, a general calculation and analysis can be performed on the different earthquakes corresponding to each rainstorm flood. The weights of various classes of the influential factors were assigned as $X_{i j}(i=1,2,3,4 ; j$ is different due to different classes of the influential factors); meanwhile, various influential factors were assigned with weight $W_{i}\left(\sum_{i=1}^{4} W_{i}=\right.$ $1.0)$; hence the general score $P$ of various earthquakes could be indicated as follows:

$$
P=\sum_{i=1}^{4} X_{i j} \times W_{i} .
$$

Regarding the weights of various influential factors, it was hypothesized that the impacts of earthquake scale and relative orientation to the rainstorm flood event on the correspondence between them were relatively high, while the time interval and distance between them would generate lower impacts.

As shown in Table 6, the weight $W_{i}$ of various influential factors was listed.
TABLE 6: Weights of various influential factors.

\begin{tabular}{lc}
\hline Influential factor & Weight \\
\hline $\begin{array}{l}\text { Earthquake scale } \\
\text { Time interval between the earthquake and the }\end{array}$ & 0.3 \\
rainstorm flood event & 0.2 \\
$\begin{array}{l}\text { Distance between the earthquake and the rainstorm } \\
\text { flood event }\end{array}$ & 0.2 \\
$\begin{array}{l}\text { Orientation of the earthquake to the rainstorm flood } \\
\text { event }\end{array}$ & 0.3 \\
\hline
\end{tabular}

According to the general score $P$, five possible correspondences between rainstorm flood events and earthquakes can be set (Table 7).

\section{Results and Analysis}

The possible correspondences between the 165 rainstorm floods and the 1,932 earthquakes that happened two years before them are calculated and shown in Table 8 .

The foregoing statistics showed that none of the 165 severe rainstorm floods had strong correspondence to the previous severe earthquakes; 99 of the severe rainstorm floods, or $58.6 \%$ of all rainstorm floods, might have a high correspondence to the severe earthquakes taking place in the past 2 years. Only 2 of the severe rainstorm floods had low correspondences to the severe earthquakes taking place in the past 2 years. Meanwhile, 144 of the 1,932 severe earthquakes had a high correspondence to the rainstorm floods that took place 2 years later, or $7.5 \%$ of all severe earthquakes, $6.1 \%$ of the preliminarily-screened 2,354 severe earthquakes, and only $5.9 \%$ of the 2,461 severe earthquakes higher than Ms6.0. 
TABLE 7: Judgment of possible correspondences between rainstorm floods and earthquakes.

\begin{tabular}{lcc}
\hline Class & General score $P$ & Possible correspondence \\
\hline Class 1 & {$[0.8,1.0]$} & Correspondence is extremely probable \\
Class 2 & {$[0.6,0.8)$} & Correspondence is highly probable \\
Class 3 & {$[0.4,0.6)$} & Correspondence is probable \\
Class 4 & {$[0.2,0.4)$} & Correspondence is impossible \\
Class 5 & {$[0.1,0.2)$} & Correspondence is highly impossible \\
\hline
\end{tabular}

TABLE 8: Summary of the probable correspondences between rainstorm floods and earthquakes.

\begin{tabular}{lcc}
\hline Class & Rainstorm flood event & Corresponding earthquake \\
\hline Class 1 & 0 & 0 \\
Class 2 & 99 & 144 \\
Class 3 & 64 & 906 \\
Class 4 & 2 & 856 \\
Class 5 & - & 26 \\
Total & 165 & 1,932 \\
\hline
\end{tabular}

It showed that most earthquakes had a low correspondence to the rainstorm floods taking place within 2 years after them.

Among the 99 rainstorm floods with a highly possible correspondence to earthquakes, 38 rainstorm floods had a high correspondence to multiple previous earthquakes, with 1 rainstorm flood corresponding to 8 severe earthquakes at the maximum. It meant that multiple earthquakes might have impacts on 1 rainstorm flood. On the contrary, 24 earthquakes of the 144 earthquakes may correspond to multiple rainstorm flood events, with 1 earthquake corresponding to 3 rainstorm floods at the maximum. This indicated that most earthquakes and rainstorm floods corresponded to each other on a oneto-one basis although one-sixth of the earthquakes might generate certain impacts on multiple rainstorm floods.

Judging from the correspondence between the numbers of grids where rainstorm floods and earthquakes were located, the grids of 36 (65.5\% of all 55 grids) rainstorm floods corresponded to the grids of multiple epicenters, with 1 grid of rainstorm flood corresponding to the grids of 11 epicenters at the maximum (including 1 rainstorm flood corresponding to multiple earthquakes). On the contrary, the grid of the same epicenter corresponded to the grids of multiple rainstorm floods, with the grid of 1 epicenter corresponding to the grids of 13 rainstorm floods at the maximum (similarly including repetitions). Accordingly, no rainstorm flood located in the same grid or some adjacent grids was found always corresponding to the earthquake of a certain grid or some adjacent grids and vice versa (Figures 3 and 4). It meant that none of the earthquakes in a certain region was always found to cause the rainstorm floods in the some regions.

Further analysis of the 99 rainstorm floods and 144 earthquakes that had a high correspondence showed that there were cumulatively 172 repeated correspondences between the rainstorm floods and the earthquakes (Figure 5). Rainstorm floods basically happened in the main rainstorm regions of China, most of which were along the Yangtze River, followed by the Pearl River and the fewest in the southwest of China, and they mostly happened during the rainy period of these regions (June to August). The earthquake scale distribution rules were similar to the general rules, and scale 7 and scale 8 earthquakes were the most. Rainstorm floods mostly occurred within 1 year after an earthquake, especially from January to March. The rainstorm zone was mostly within $3,000 \mathrm{~km}$ away from the epicenter, particularly between $1,000 \mathrm{~km}$ and $2,000 \mathrm{~km}$. Earthquake zones were mostly located to the west or southwest of the rainstorm zones and on the path of exotic vapors towards the rainstorm zones. Meanwhile, the four influential factors were all very important to the general score during the survey of the same rainstorm flood corresponding to multiple earthquakes. However, none of the influential factors played a decisive role in the general score (Table 9).

\section{Discussions}

Through the summarization of the severe earthquakes and the rainstorm floods that may have spatial and temporal correspondence in China and adjacent regions in the past $200+$ years and also by general computation and statistical analysis, it was found that only 144 severe earthquakes had a high correspondence with the rainstorm floods that occurred within 2 years after their occurrence, or only $5.9 \%$ of the 2,461 severe earthquakes higher than Ms6.5. As we all know, this computation and statistical results were based on some parameters and weights, and the values of weights are subjective and could be criticized. So we need to change the weights values, computation, and statistical analysis again.

First, we will change the weights values of the influential factors. The results are shown in Table 10.

The data in Table 10 shows different distribution ratios of the four factors' weights; the statistical results are different. The greater the differentiation of the distribution ratios, the higher the corresponding number. In the four factors, the weights of orientation bear the biggest influence on statistical results; the bigger the weights of orientation, the higher the corresponding number. Increasing the weights of orientation and distance, the corresponding number of class 1 is also on the increase. In order to prevent the single factor's influence on the statistical results, we set the weights as the above (Table 6); it is very reasonable.

Now, we come to have a further discussion about the rules of the high corresponding relationships between earthquakes and rainstorm floods. In order to obtain more earthquake series, we shuffled the earthquake occurring time, location, and magnitude of the former earthquake series, respectively and randomly, to form a new set of earthquake series [60] (diagram as shown in Figure 6). The synthetic earthquake series and the original rainstorm flood series were input to the model; after calculation the statistical results were shown in Table 11.

We analyzed the regularity of the correspondence results and found that there were still no rules in the correspondence. It is consistent with the analysis results in Section 4. 


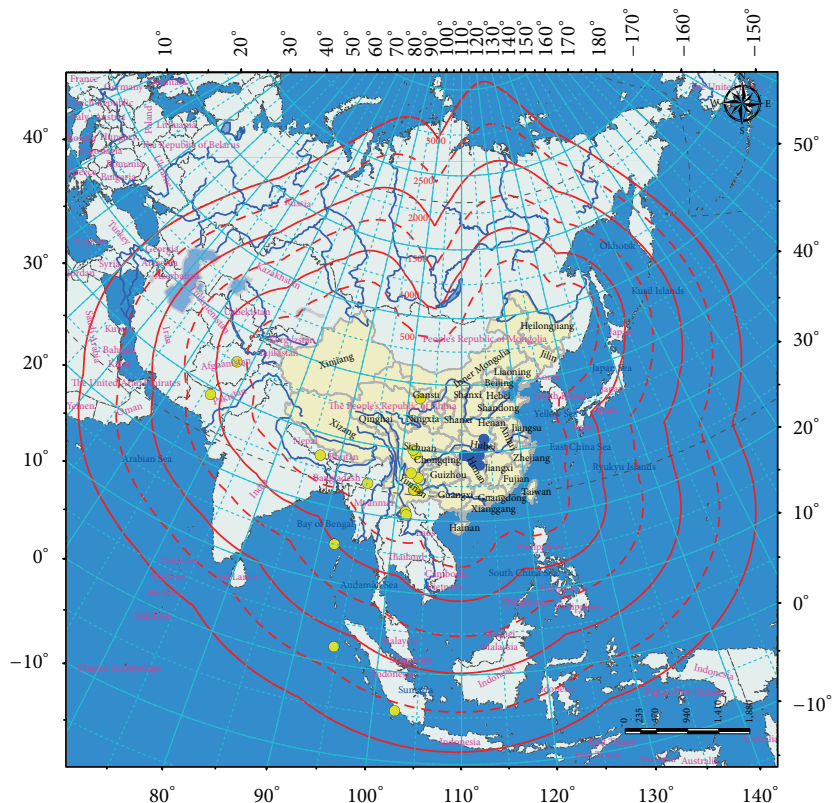

- Rainstorm center

- Earthquakes

- Main rivers

\section{r- - Distance to China \\ Country}

(a)

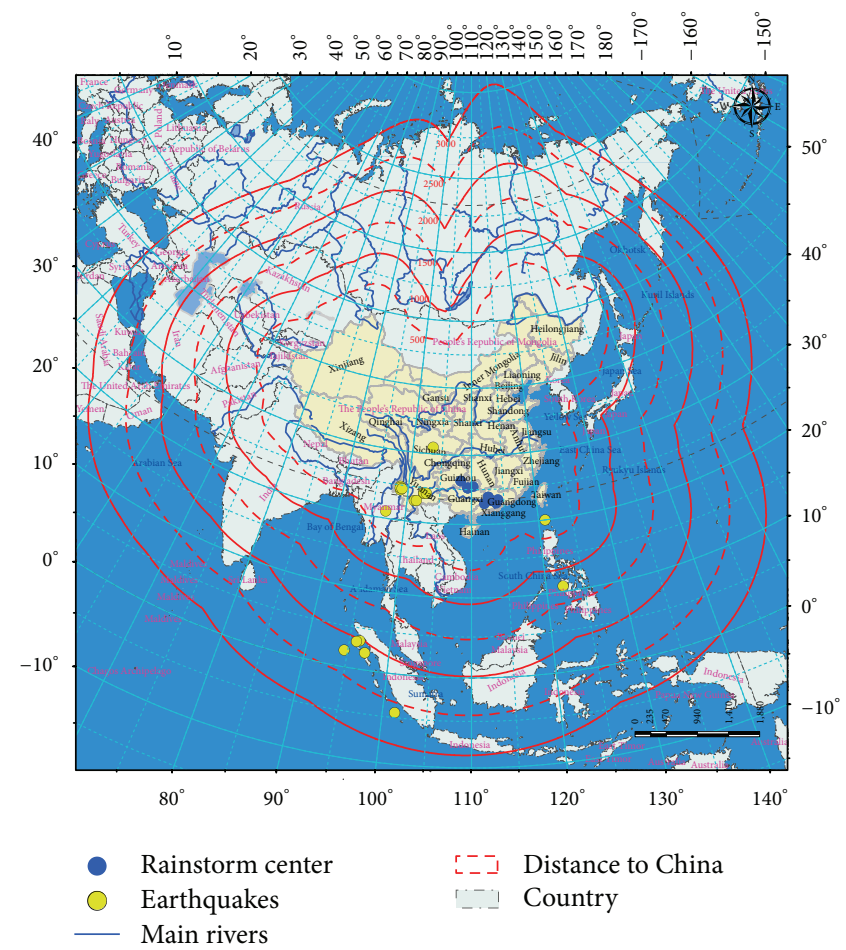

(b)

FIGURE 3: Distribution of typical regional rainstorm floods and previous earthquakes.
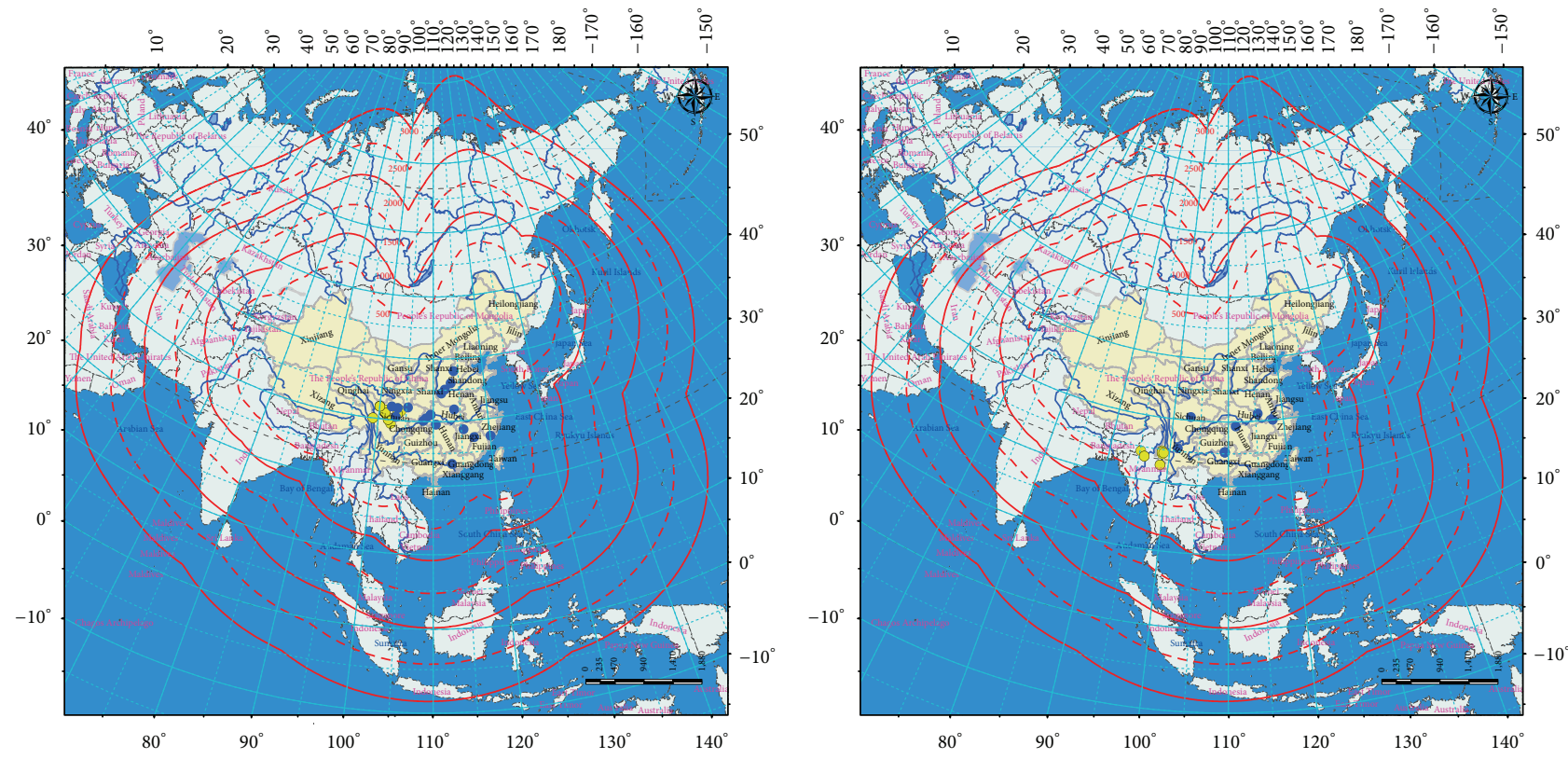

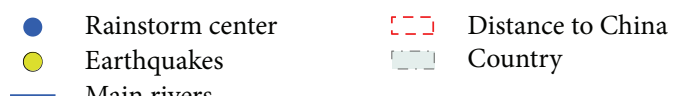

- Earthquakes

- Main rivers

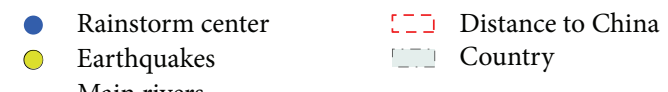

(b)

FIGURE 4: Distribution of typical regional earthquakes and subsequent rainstorm floods. 
TABLE 9: Summary of the correspondences between the 99 rainstorm floods and the 144 earthquakes.

\begin{tabular}{lcccccccc}
\hline \multicolumn{2}{c}{ Drainage area or region } & \multicolumn{2}{c}{ Magnitude } & \multicolumn{2}{c}{ Time interval (month) } & \multicolumn{2}{c}{ Distance $(\mathrm{km})$} & \multicolumn{2}{c}{ Orientation } \\
Name & Count & Class & Count & Class & Count & Class & Count & Orientation difference \\
Count
\end{tabular}

TABLE 10: The correspondence results based on different weights values of the influential factors.

\begin{tabular}{|c|c|c|c|c|c|c|c|c|c|}
\hline \multicolumn{4}{|c|}{ Weights } & \multicolumn{2}{|c|}{ Class 1} & \multicolumn{2}{|c|}{ Class 2} & \multicolumn{2}{|c|}{ Classes 1 and 2} \\
\hline Magnitude & $\begin{array}{c}\text { Time } \\
\text { interval }\end{array}$ & Distance & Orientation & Rainstorm flood & Earthquake & Rainstorm flood & Earthquake & Rainstorm flood & Earthquake \\
\hline 1 & 0 & 0 & 0 & 23 & 9 & 53 & 30 & 76 & 39 \\
\hline 0 & 1 & 0 & 0 & 156 & 610 & 3 & 746 & 159 & 1356 \\
\hline 0 & 0 & 1 & 0 & 154 & 589 & 11 & 601 & 165 & 1190 \\
\hline 0 & 0 & 0 & 1 & 160 & 785 & 0 & 0 & 160 & 785 \\
\hline 0.7 & 0.1 & 0.1 & 0.1 & 2 & 2 & 33 & 18 & 35 & 20 \\
\hline 0.1 & 0.7 & 0.1 & 0.1 & 71 & 113 & 87 & 740 & 158 & 853 \\
\hline 0.1 & 0.1 & 0.7 & 0.1 & 32 & 60 & 128 & 668 & 160 & 728 \\
\hline 0.1 & 0.1 & 0.1 & 0.7 & 110 & 179 & 50 & 605 & 160 & 784 \\
\hline 0.4 & 0.2 & 0.2 & 0.2 & 1 & 1 & 37 & 34 & 38 & 35 \\
\hline 0.2 & 0.4 & 0.2 & 0.2 & 1 & 1 & 136 & 337 & 137 & 338 \\
\hline 0.2 & 0.2 & 0.4 & 0.2 & 1 & 1 & 129 & 312 & 130 & 313 \\
\hline 0.2 & 0.2 & 0.2 & 0.4 & 0 & 0 & 148 & 437 & 148 & 437 \\
\hline 0.4 & 0.4 & 0.1 & 0.1 & 1 & 1 & 61 & 58 & 62 & 59 \\
\hline 0.4 & 0.1 & 0.4 & 0.1 & 0 & 0 & 45 & 33 & 45 & 33 \\
\hline 0.4 & 0.1 & 0.1 & 0.4 & 1 & 1 & 89 & 91 & 90 & 92 \\
\hline 0.1 & 0.4 & 0.4 & 0.1 & 15 & 16 & 137 & 603 & 152 & 619 \\
\hline 0.1 & 0.4 & 0.1 & 0.4 & 41 & 44 & 115 & 527 & 156 & 571 \\
\hline 0.1 & 0.1 & 0.4 & 0.4 & 32 & 42 & 120 & 505 & 152 & 547 \\
\hline 0.3 & 0.3 & 0.3 & 0.1 & 0 & 0 & 78 & 115 & 78 & 115 \\
\hline 0.3 & 0.3 & 0.1 & 0.3 & 1 & 1 & 107 & 174 & 108 & 175 \\
\hline 0.3 & 0.1 & 0.3 & 0.3 & 0 & 0 & 100 & 158 & 100 & 158 \\
\hline 0.25 & 0.25 & 0.25 & 0.25 & 0 & 0 & 124 & 226 & 124 & 226 \\
\hline 0.3 & 0.2 & 0.2 & 0.3 & 0 & 0 & 99 & 144 & 99 & 144 \\
\hline
\end{tabular}

\section{Conclusions}

Currently, there is a big controversy surrounding the topic of EDE. Under the hypothesis that EDE is valid, this paper tests the relationship between rainstorm floods and earthquakes. When EDE is substantiated, it is believed that most of the rainstorm floods may relate to severe earthquakes. However, most of the rainstorm floods have nothing to do with the severe earthquakes from a statistical perspective.

The foregoing calculation showed that the correspondence between a severe earthquake and a rainstorm flood was related to the earthquake scale, geographic location of 
TABLE 11: The correspondence results based on shuffled series of earthquakes.

\begin{tabular}{|c|c|c|c|c|c|c|c|c|}
\hline \multicolumn{3}{|c|}{ Shuffle or not } & \multicolumn{2}{|c|}{ Class 1} & \multicolumn{2}{|c|}{ Class 2} & \multicolumn{2}{|c|}{ Classes 1 and 2} \\
\hline Time & $\begin{array}{l}\text { Epicenter } \\
\text { location }\end{array}$ & Earthquake scale & Rainstorm flood & Earthquake & Rainstorm flood & Earthquake & Rainstorm flood & Earthquake \\
\hline Yes & No & No & 2 & 2 & 111 & 151 & 113 & 153 \\
\hline No & Yes & No & 2 & 1 & 115 & 142 & 117 & 143 \\
\hline No & No & Yes & 4 & 2 & 96 & 134 & 100 & 136 \\
\hline Yes & Yes & No & 3 & 2 & 94 & 133 & 97 & 135 \\
\hline Yes & No & Yes & 1 & 1 & 91 & 121 & 92 & 122 \\
\hline No & Yes & Yes & 3 & 2 & 93 & 146 & 96 & 148 \\
\hline Yes & Yes & Yes & 0 & 0 & 101 & 143 & 101 & 143 \\
\hline
\end{tabular}

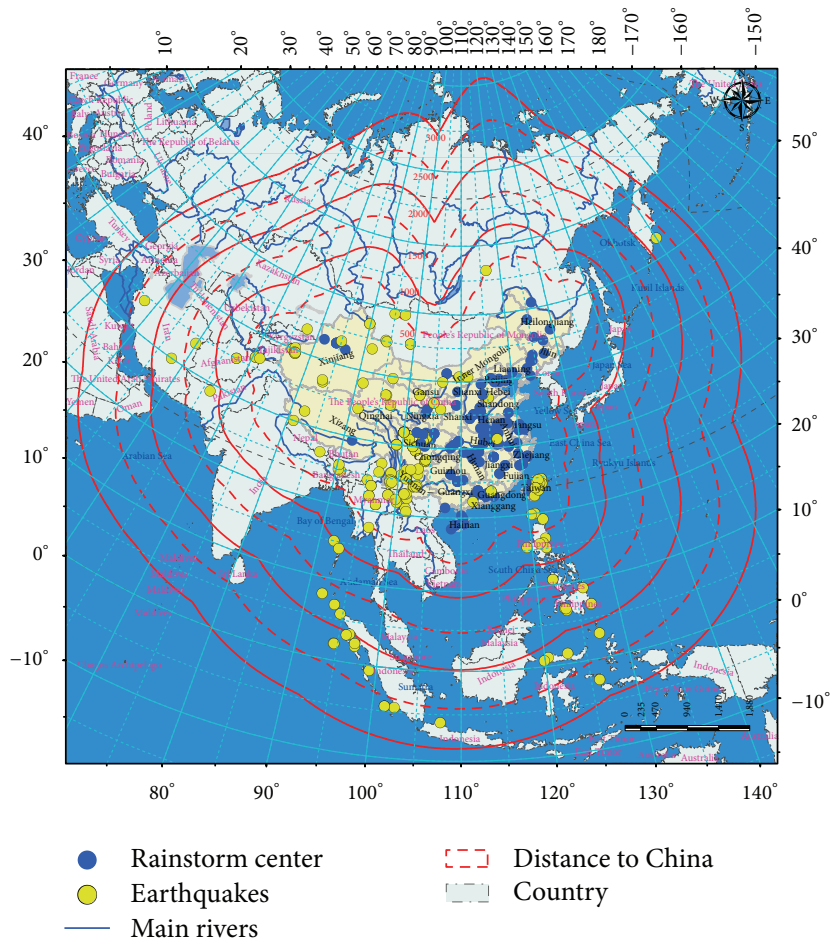

FIGURE 5: General distribution of the 144 earthquakes corresponding to the 99 rainstorm floods.

\begin{tabular}{lccc}
\hline Number & Time & Epicenter location & Earthquake scale \\
\hline 1 & 1812.3 .8 & $83.0^{\circ} \mathrm{E}, 43.7^{\circ} \mathrm{N}$ & 7.8 \\
2 & 1906.3 .28 & $118.5^{\circ} \mathrm{E}, 24.5^{\circ} \mathrm{N}$ & 6.5 \\
3 & 1922.5 .15 & $144.2^{\circ} \mathrm{E}, 40.3^{\circ} \mathrm{N}$ & 6.5 \\
4 & 1938.8 .16 & $93.9^{\circ} \mathrm{E}, 23.0^{\circ} \mathrm{N}$ & 7.1 \\
5 & 1948.5 .25 & $100.5^{\circ} \mathrm{E}, 29.5^{\circ} \mathrm{N}$ & 7.3 \\
6 & 1976.7 .28 & $118.0^{\circ} \mathrm{E}, 39.4^{\circ} \mathrm{N}$ & 7.8 \\
7 & 1990.2 .8 & $124.6^{\circ} \mathrm{E}, 9.8^{\circ} \mathrm{N}$ & 6.8 \\
8 & 2000.6 .4 & $102.0^{\circ} \mathrm{E}, 4.8^{\circ} \mathrm{S}$ & 7.8 \\
9 & 2004.12 .26 & $95.86^{\circ} \mathrm{E}, 3.27^{\circ} \mathrm{N}$ & 9.3 \\
10 & 2008.5 .12 & $103.4^{\circ} \mathrm{E}, 31.0^{\circ} \mathrm{N}$ & 8.0 \\
\hline
\end{tabular}

\begin{tabular}{cccc}
\cline { 2 - 4 } Number & Time & Epicenter location & Earthquake scale \\
\cline { 2 - 4 } 1 & 2008.5 .12 & $118.0^{\circ} \mathrm{E}, 39.4^{\circ} \mathrm{N}$ & 6.8 \\
2 & 1938.8 .16 & $144.2^{\circ} \mathrm{E}, 40.3^{\circ} \mathrm{N}$ & 7.8 \\
3 & 2004.12 .26 & $93.9^{\circ} \mathrm{E}, 23.0^{\circ} \mathrm{N}$ & 6.5 \\
\hline & 1906.3 .28 & $124.6^{\circ} \mathrm{E}, 9.8^{\circ} \mathrm{N}$ & 7.8 \\
5 & 2000.6 .4 & $118.5^{\circ} \mathrm{E}, 24.5^{\circ} \mathrm{N}$ & 9.3 \\
6 & 1922.5 .15 & $83.0^{\circ} \mathrm{E}, 43.7^{\circ} \mathrm{N}$ & 8.0 \\
7 & 1990.2 .8 & $100.5^{\circ} \mathrm{E}, 29.5^{\circ} \mathrm{N}$ & 7.3 \\
8 & 1948.5 .25 & $103.4^{\circ} \mathrm{E}, 31.0^{\circ} \mathrm{N}$ & 7.1 \\
9 & 1812.3 .8 & $95.86^{\circ} \mathrm{E}, 3.27^{\circ} \mathrm{N}$ & 7.8 \\
10 & 1976.7 .28 & $102.0^{\circ} \mathrm{E}, 4.8^{\circ} \mathrm{S}$ & 6.5 \\
\hline
\end{tabular}

FIGURE 6: Schematic diagram of shuffling the series of earthquakes. 
the rainstorm zone, and epicenter as well as the time interval, distance, and relative orientation between the rainstorm flood and the earthquake. Therefore, it is highly probable for an earthquake to spark off a severe rainstorm flood if the earthquake is located on the transmission path of vapors leading to the rainstorm.

From a statistical point of view, some severe earthquakes and rainstorm floods have certain intrinsic linkage. From a physical perspective, however, it is necessary to carry out a further systematic research on the impacts of orientation, scope, time interval, and weather system of an earthquake on rainstorm floods.

\section{Competing Interests}

The authors declare that they have no competing interests.

\section{Acknowledgments}

The research is financially supported by the National Natural Science Foundation of China (Grant no. 51509267) and the National Basic Research Program of China ("973" Program) (Grants nos. 2013CB036406 and 2015CB452701). Thanks are due to Dr. Yuyan Zhou in China Institute of Water Resources and Hydropower Research and Professors Quansheng Liu and Jinxing $\mathrm{Xu}$ for assisting in revising this paper.

\section{References}

[1] United Nations Office for Disaster Risk Reduction (UNISDR), Global Assessment Report on Disaster Risk Reduction, United Nations Office for Disaster Risk Reduction (UNISDR), Geneva, Switzerland, 2009.

[2] M. J. Crozier, "Deciphering the effect of climate change on landslide activity: a review," Geomorphology, vol. 124, no. 3-4, pp. 260-267, 2010.

[3] D.-H. Yang, D.-B. Yang, and X.-X. Yang, "The influence of tides and earthquakes in global climate changes," Chinese Journal of Geophysics, vol. 54, no. 4, pp. 926-934, 2011.

[4] A. Bunde, J. Kropp, and H. J. Schellnhuber, Eds., The Science of Disasters: Climate Disruptions, Heart Attacks, and Market Crashes, Springer, Berlin, Germany, 2002.

[5] A. De Santis, "Geosystemics," in Proceedings of the 3rd IASME/WSEAS International Conference on Geology and Seismology (GES '09), pp. 36-40, Cambridge, UK, February 2009.

[6] S. Homma, K. Fujita, and T. Ichimura, "A physics-based monte carlo earthquake disaster simulation accounting for uncertainty in building structure parameters," Procedia Computer Science, vol. 29, pp. 855-865, 2014.

[7] J. Li and C. K. Chen, "Modeling the dynamics of disaster evolution along causality networks with cycle chains," Physica A: Statistical Mechanics and Its Applications, vol. 401, pp. 251264, 2014.

[8] H. Hasanzadeh and M. Bashiri, "An efficient network for disaster management: model and solution," Applied Mathematical Modelling, vol. 40, no. 5-6, pp. 3688-3702, 2016.

[9] Q. W. Li, C. Wang, and H. Zhang, "A probabilistic framework for hurricane damage assessment considering non-stationarity and correlation in hurricane actions," Structural Safety, vol. 59, pp. 108-117, 2016.
[10] S. C. Li, Z. Q. Zhou, L. P. Li, P. Lin, Z. Xu, and S. Shi, "A new quantitative method for risk assessment of geological disasters in underground engineering: Attribute Interval Evaluation Theory (AIET)," Tunnelling and Underground Space Technology, vol. 53, pp. 128-139, 2016.

[11] K. S. Sagun-Ongtangco, M. A. D. Abenir, C. T. Bermejo, E. D. C. Shih, J. V. O. Wales, and J. Plaza, "Perspectives of the UST NSTP facilitators on disability and disaster risk reduction and management: a qualitative case study," International Journal of Disaster Risk Reduction, vol. 16, pp. 134-141, 2016.

[12] T. Nagatani, "Chain-reaction crash on a highway in high visibility," Physica A: Statistical Mechanics and Its Applications, vol. 450, pp. 466-472, 2016.

[13] R. Thom, Structural Stability and Morphogenesis, W. A. Benjamin, New York, NY, USA, 1972.

[14] D. Liu, J. Wang, and Y. Wang, "Application of catastrophe theory in earthquake hazard assessment and earthquake prediction research," Tectonophysics, vol. 167, no. 2-4, pp. 179-186, 1989.

[15] M. Scheffer, S. Carpenter, J. A. Foley, C. Folke, and B. Walker, "Catastrophic shifts in ecosystems," Nature, vol. 413, no. 6856, pp. 591-596, 2001.

[16] G. Woo, Calculating Catastrophe, Imperial College Press, 2011.

[17] D. L. Turcotte, Fractals and Chaos in Geology and Geophysics, Cambridge University Press, Cambridge, UK, 1997.

[18] S. A. Shapiro, E. Huenges, and G. Borm, "Estimating the crust permeability from fluid-injection-induced seismic emission at the KTB site," Geophysical Journal International, vol. 131, no. 2, pp. F15-F18, 1997.

[19] N. Delépine, N. Cuenot, E. Rothert, M. Parotidis, S. Rentsch, and S. A. Shapiro, "Characterization of fluid transport properties of the Hot Dry Rock reservoir Soultz-2000 using induced microseismicity," Journal of Geophysics and Engineering, vol. 1, no. 1, pp. 77-83, 2004.

[20] N. Deichmann and D. Giardini, "Earthquakes induced by the stimulation of an enhanced geothermal system below Basel (Switzerland)," Seismological Research Letters, vol. 80, no. 5, pp. 784-798, 2009.

[21] P. Talwani, "Seismogenic properties of the crust inferred from recent studies of reservoir-induced seismicity-application to Koyna," Current Science, vol. 79, no. 9, pp. 1327-1333, 2000.

[22] M.-K. Lee- and L. W. Wolf, "Analysis of fluid pressure propagation in heterogeneous rocks: implications for hydrologicallyinduced earthquakes," Geophysical Research Letters, vol. 25, no. 13, pp. 2329-2332, 1998.

[23] M. Parotidis, E. Rothert, and S. A. Shapiro, "Pore-pressure diffusion: a possible triggering mechanism for the earthquake swarms 2000 in Vogtland/NW-Bohemia, central Europe," Geophysical Research Letters, vol. 30, no. 20, 2003.

[24] S. A. Shapiro, E. Rothert, V. Rath, and J. Rindschwentner, "Characterization of fluid transport properties of reservoirs using induced microseismicity," Geophysics, vol. 67, no. 1, pp. 212-220, 2002.

[25] S. A. Shapiro, C. Dinske, C. Langenbruch, and F. Wenzel, "Seismogenic index and magnitude probability of earthquakes induced during reservoir fluid stimulations," Leading Edge, vol. 29, no. 3, pp. 304-309, 2010.

[26] B. P. Goertz-Allmann, A. Goertz, and S. Wiemer, "Stress drop variations of induced earthquakes at the Basel geothermal site," Geophysical Research Letters, vol. 38, no. 9, 2011.

[27] A. Díaz-Moreno, J. M. Ibáñez, S. De Angelis et al., "Seismic hydraulic fracture migration originated by successive deep 
magma pulses: the 2011-2013 seismic series associated to the volcanic activity of El Hierro Island," Journal of Geophysical Research: Solid Earth, vol. 120, no. 11, pp. 7749-7770, 2015.

[28] W. Bosl and A. Nur, "Aftershocks and pore fluid diffusion following the Landers earthquake," Journal of Geophysical Research, vol. 107, no. B12, p. 2366, 1992.

[29] S. A. Shapiro, R. Patzig, E. Rothert, and J. Rindschwentner, "Triggering of seismicity by pore-pressure perturbations: permeability-related signatures of the phenomenon," Pure and Applied Geophysics, vol. 160, no. 5-6, pp. 1051-1066, 2003.

[30] S. A. Shapiro, S. Rentsch, and E. Rothert, "Characterization of hydraulic properties of rocks using probability of fluid-induced microearthquakes," Geophysics, vol. 70, no. 2, pp. F27-F33, 2005.

[31] B. W. Levin, "Nonlinear oscillating structures in the earthquake and seaquake dynamics," Chaos, vol. 6, no. 3, pp. 405-413, 1996.

[32] C. D. Williams, "The Mary Celeste: a classic seaquake encounter?" Marine Observer, vol. 72, no. 355, 2002.

[33] F. Dall'Osso, D. Dominey-Howes, C. Moore, S. Summerhayes, and G. Withycombe, "The exposure of Sydney (Australia) to earthquake-generated tsunamis, storms and sea level rise: a probabilistic multi-hazard approach," Scientific Reports, vol. 4, article 7401, 2014.

[34] J. Mohammand and P. Grobbel, "An investigation of earthquake fire hazard in urban areas," in Proceedings of the World Conference on Earthquake Engineering (WCEE '96), Acapulco, Mexico, June 1996.

[35] M. Kobayashi, "Urban post-earthquake fires in Japan," in Proceedings of the 2nd Japan-US Workshop on Urban Earthquake Hazard Reduction, 2002.

[36] G. Papadopoulos, "Tsunami early warning systems and risk mitigation," in Tsunamis in the European-Mediterranean Region, pp. 179-226, 2016.

[37] E. Okemwa, "The Intergovernmental Oceanographic Commission of UNESCO and regional capacity building," Marine Policy, vol. 22, no. 3, pp. 197-207, 1998.

[38] Y. Q. Wang and Q. Hou, "Earthquake flood disaster chainresearch on early-stage earthquakes of super-scale floods on Xijiang River in the past 500 years," in Proceedings of the Natural Disaster Forecast and Summarization Academic Workshop, Beijing, China, 2010 (Chinese).

[39] Z. J. Guo, B. Y. Qin, and G. P. Li, "Remote relevancy between severe Earthquake, severe flood and severe drought," Northwest Earthquake Journal, no. 3, article 37, 1991 (Chinese).

[40] L. T. Du, "Significance research and development of earth degassing," Geological Review, vol. 51, no. 2, pp. 174-180, 2005 (Chinese).

[41] G. Chiodini, C. Cardellini, A. Amato et al., "Carbon dioxide Earth degassing and seismogenesis in central and southern Italy," Geophysical Research Letters, vol. 31, no. 7, Article ID L07615, 2004.

[42] E. A. Gaiduk, Y. D. Fomin, V. N. Ryzhov, E. N. Tsiok, and V. V. Brazhkin, "Dynamical crossover in supercritical core-softened fluids," Fluid Phase Equilibria, vol. 417, pp. 237-241, 2016.

[43] A. Rauen, J. Duyster, S. Heikamp et al., "Electrical conductivity of a KTB core from $7000 \mathrm{~m}$ : effects of cracks and ore minerals," Scientific Drilling, vol. 4, no. 5-6, pp. 197-206, 1994.

[44] B. N. Khakhaev, L. A. Pevzner, I. I. Samkhan et al., "Geothermal technology of formation water utilization," Razvedka I Okhrana Nedr, no. 1, pp. 34-36, 1994.

[45] I. A Garagash, V. N. Nikolaevsky, and V. I. Shatilov, "Connection of the deep anomalies of the crust stresses with under salt hydrocarbon deposits of the North Caspian," in Proceedings of the RAS, vol. 338, pp. 383-386, 1994.

[46] A. Caracausi, M. Martelli, P. M. Nuccio, M. Paternoster, and F. M. Stuart, "Active degassing of mantle-derived fluid: a geochemical study along the Vulture line, southern Apennines (Italy)," Journal of Volcanology and Geothermal Research, vol. 253, pp. 65-74, 2013.

[47] P. Sella, A. Billi, I. Mazzini et al., "A newly-emerged (August 2013) artificially-triggered fumarole near the Fiumicino airport, Rome, Italy," Journal of Volcanology and Geothermal Research, vol. 280, pp. 53-66, 2014.

[48] V. I. Vernadsky, "Gas exchange in earth's crust," Proceedings of St. Petersburg Royal Academy of Sciences, vol. 6, pp. 141-162, 1912 (Russian).

[49] W. W. Rubey, "Geologic history of sea water: an attempt to state the problem," Geological Society of America Bulletin, vol. 62, pp. 1111-1148, 1951.

[50] V. M. Goldschmidt, “Geochemistry," Soil Science, vol. 78, no. 2, p. 156, 1954.

[51] F. P. Fanale, "A case for catastrophic early degassing of the earth," Chemical Geology, vol. 8, no. 2, pp. 79-105, 1971.

[52] D. K. Bailey, "Volcanism, earth degassing and replenished lithosphere mantle," Philosophical Transactions of the Royal Society A: Mathematical, Physical \& Engineering Sciences, vol. 297, no. 1431, pp. 309-322, 1980.

[53] T. Gold, "The deep, hot biosphere," Proceedings of the National Academy of Sciences of the United States of America, vol. 89, no. 13, pp. 6045-6049, 1992.

[54] F. Pineau and M. Javoy, "Strong degassing at ridge crests: the behaviour of dissolved carbon and water in basalt glasses at $14^{\circ} \mathrm{N}$, Mid-Atlantic Ridge," Earth and Planetary Science Letters, vol. 123, no. 1-3, pp. 179-198, 1994.

[55] H.-F. Graf, B. Langmann, and J. Feichter, "The contribution of Earth degassing to the atmospheric sulfur budget," Chemical Geology, vol. 147, no. 1-2, pp. 131-145, 1998.

[56] G. Chiodini, F. Frondini, C. Cardellini, F. Parello, and L. Peruzzi, "Rate of diffuse carbon dioxide Earth degassing estimated from carbon balance of regional aquifers: the case of central Apennine, Italy," Journal of Geophysical Research: Solid Earth, vol. 105, no. 4, Article ID 1999JB900355, pp. 8423-8434, 2000.

[57] Z. J. Qiang, X. D. Xu, and C. G. Dian, "Thermal infrared anomaly precursor of impending earthquakes," Chinese Science Bulletin, vol. 36, no. 4, pp. 319-323, 1991.

[58] Y. Sano, N. Takahata, G. Igarashi, N. Koizumi, and N. C. Sturchio, "Helium degassing related to the Kobe earthquake," Chemical Geology, vol. 150, no. 1-2, pp. 171-179, 1998.

[59] G. W. Liu, Atmospheric Process of Hydrological Circulation, Science Press, Beijing, China, 1997 (Chinese).

[60] J. Theiler, S. Eubank, A. Longtin, B. Galdrikian, and J. Doyne Farmer, "Testing for nonlinearity in time series: the method of surrogate data," Physica D: Nonlinear Phenomena, vol. 58, no. 1-4, pp. 77-94, 1992. 

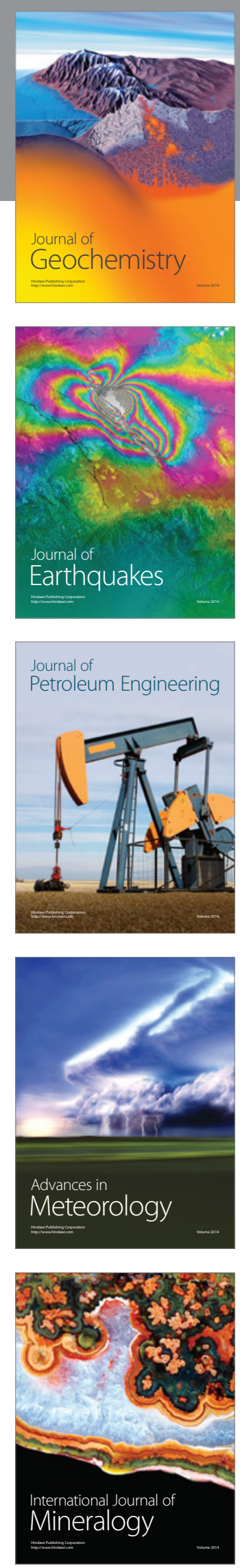
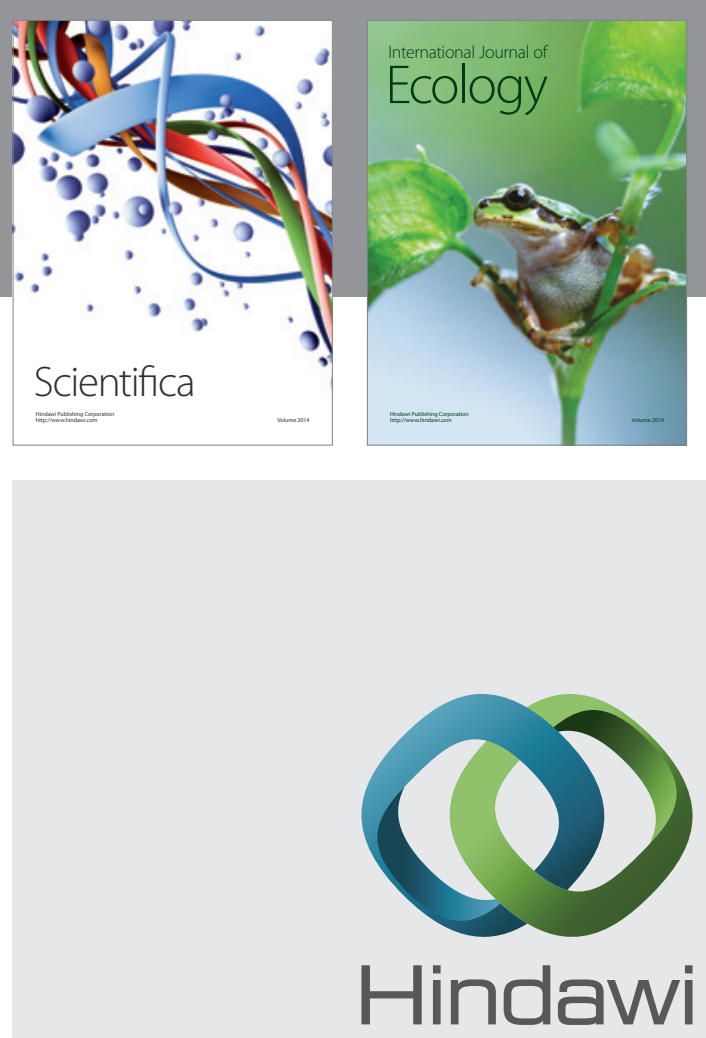

Submit your manuscripts at

http://www.hindawi.com
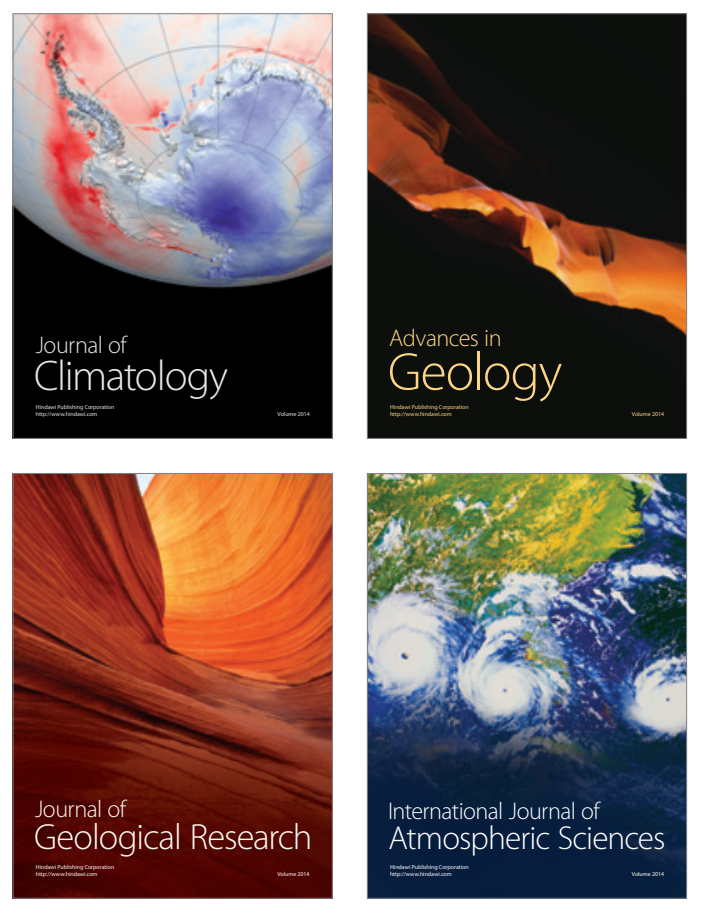

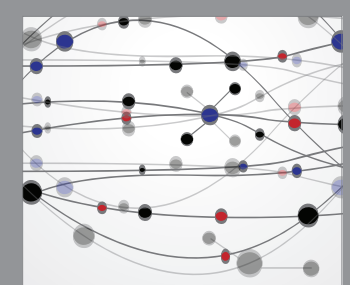

The Scientific

\section{World Journal}
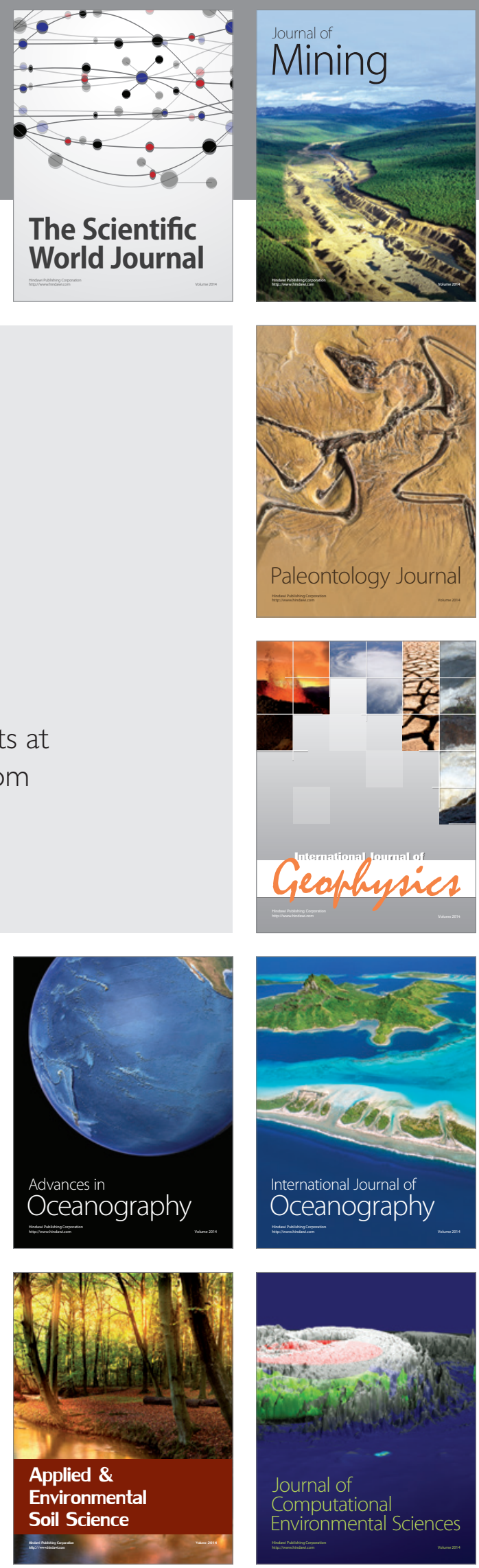